\title{
STRUCTURE OF ISOLATED PRECISION FACTORS OF THE MALE VOLLEYBALL PLAYERS
}

\author{
Tamara Karalić ${ }^{1}$, Nenad Marelić ${ }^{2}$, and Aleksandra Vujmilović \\ ${ }^{1}$ Faculty of Physical Education and Sport, University of Banja Luka, \\ Bosnia and Herzegovina \\ ${ }^{2}$ Faculty of Kinesiology, Univerzity of Zagreb, Croatia \\ ${ }^{3}$ Medical High Scool, Banja Luka, Bosnia and Herzegovina
}

\section{SUMMARY}

The subject of this research project is precision as a factor of success of the male volleyball players. The issue relates to the realization of the said motor skills through a clearly defined and valid metric tests typical for the area of technical - tactical structure of volleyball. The aim of the study was to determine the factorial structure of motor abilities of precision for male volleyball players. The task was to determine the correlation between motor tasks with the main components defined as potential factors of the research area. The sample consisted of 40 male volleyball players, members of volleyball teams from Niš (SRB), 14-16 years of age. Eleven motor tests were used to assess the following potential factors: the precision of shooting targets in the horizontal plane, the precision of shooting targets in the vertical plane, body coordination at the volleyball court, the precision of spike technique and nerve-muscle reactions.

It was found that there are certain manifest dimensions within the subjects area defined as the area of precision. Then, in the structure of this region in volleyball, acting as precision factors in shooting targets with fingers and "bump" in the horizontal and vertical planes, also confirmed that the coordination of work and factor in the space of volleyball courts and a velocity factor of nervemuscle response.

In general it is concluded that within the structure of technical-tactical elements operate particular types of precision in volleyball, that can be defined as factors of precision in the technique of adding a ball with fingers, forearm pass technique ("bump") and spike technique.

Key Words: technical-tactical stuctures, factors, precision, volleyball.

\section{INTRODUCTION}

In every sporting activity, even in volleyball, there is no technical element that can be properly carried out without adequate motor skills, nor can any motor ability be fully manifested without rational technique. So it is inconceivable to talk about the development and improvement of motor skills in isolation from the development and refinement of motor skills and habits. This research paper considered the application of precision motor ability tests based on all the existing knowledge about relationship of motor ability and motor skills. The idea is to congregate in one place material facts associated with a specific motor skill, such as precision.

The issues related to precision are studied by many authors. Their findings cover mainly the area of the structure of outplaying by female volleyball players and male volleyball players and solving motor tasks in situational training or volleyball competition. (Бернстеин, 1990; Gajić, 2005; Janković, 1988; Karalić, 2007; Аяхова \& Стрельникова, 2007; Немцев, 2003; Nešić, 2006; Stojanović \& Milenkoski, 2005). Most papers dealt with problems in terms of only some parts of the game structure, or discuss the factors which are directly or indirectly related to the structure of competitive activity. 
One of the important questions that permeates through the research conducted so far is the question of reliability and validity of tests for the so-called situational-motor precision and situational-motor tests in volleyball. (Strahonja 1978; Strahonja, Janković \& Šnajder, 1982).

In the manifest and latent motor area, the precision is defined as a special volleyball skill. In the latent motor area, there are two modes of motor precision: precision of shooting and precision of targeting. (Janković, 1988; Stojiljković, 2003). Precision of shooting is characteristic for volleyball. If we are already talking about the types of volleyball precision, let us also add what particularly stand out: precision of adding with fingers, precision of adding with the forearms, serving precision and spike precision (Bosnar \& Šnajder, 1983; Horga, Momirović, \& Janković, 1983). So it appears as an integral part of all elements of the TT elements (serving, spike, settings, block, services reception and defense).

So, the subject of this research is the precision as factor of success of male volleyball players. The specific problem relates to the implementation of the precision of motor skills through clearly defined and valid metric tests characteristic of the space technical - tactical structure of volleyball. The aim of the research was to determine the factor structure of motor abilities of precision for male volleyball players. The task is to determine the correlation between motor tasks with the main components, defined as potential factors of the study area for male volleyball players.

\section{METHODS}

\section{Entitiy sample}

The sample consisted of 40 male volleyball players members of volleyball teams from Niš (»Niš«, »As«, and »Student $\ll$ ). The subjects in the sample were 14 to 16 years old male volleyball players from the selection of cadets, with an average of 4-6 years of training program. The sample is interesting because it is about the age and period when they move from the universal model of play to the specialized model. It is time when we are trying to find their appropriate functions, taking into consideration also the features, characteristics and especially the abilities of cadet male volleyball players, who are undoubtedly, closely connected with the realization of the success on tests of precision.

\section{Variables sample}

In this reaserch eleven motor tests were used to assess the following potential factors: precision of shooting targets in the horizontal plane, precision of shooting targets in the vertical plane, the coordination of body at the volleyball court, precision of spike techniques, muscular and nervous reactions.

Motor tests are defined as follows: shooting the horizontal target with fingers (SHTF); shooting the horizontal target with the forearms (SHTB); shooting the vertical target with fingers (SVTF); shooting the vertcal target with »bump« (SVTB); shooting the target in the horizontal plane from position 2 (STHP2); shooting the horizontal target with spike technique (SPIKE); one-hand juggling a ball through a hoop $(\mathrm{OHJ})$; test coordination by the volleyball net (KOONET); test coordination in the space (KOOSP); hexagon test (HEX) and test falling rod (REFL).

\section{Statistical analysis}

To process the obtained data we used methods of descriptive statistics and factor analysis. The structure of motor precision was determined by Hotelling's method of principal components. Number of significant principal components was determined by using Gutman-Kraiser's criteria. Correlation analysis was used to measure the correlation between the applied motor tests with the main components defined as a potential factors of precision area for male volleyball players.

\section{RESULTS AND DISCUSSION}

\section{Basic statistical parameters of male volleyball players}

Regarding Table 1, the arithmetic mean $(M)$ at the sample of male volleyball players $(n=40)$ and for the motor test shooting the horizontal target with fingers (SHTF) was $15.0 \pm 1.09$, for shooting the horizontal target with the »bump« (SHTB) was $9.35 \pm 1.93$, for motor test shooting the vertical target with fingers (SVTF) the Mean is $20.07 \pm 2.27$ and for the motor test shooting the vertcal target with »bump« (SVTB) it was $10.95 \pm 1.20$. For the motor test shooting the target in the horizontal plane from position 2 (STHP2) the Mean was $9.93 \pm 1.53$. For sample of male volleyball players the Mean of motor tests shooting the horizontal target with spike technique (SPIKE) was $18.2 \pm 1.79$ and for motor tests one-hand juggling a ball through a hoop $(\mathrm{OHJ})$ was $12.77 \pm 1.44$. The Mean of motor tests coordination by the volleyball net (KOONET) were $5.93 \pm .45$ and coordination in the space (KOOPRO), 7.93 \pm .55 . The Mean of test hexagon test (HEX) to measure agility was $22.82 \pm$ .96 and motor tests to assess reaction time: a test falling rod (REFL) $15.65 \pm 1.00$. 
Variational width (Var. width) ranging from minimum (MIN) to maximum $(M A X)$ value is less than 6 or $( \pm 3)$ standard deviations. A sample of volleyball players was selected by the quality of execution of technical elements, in accordance to age categories, limited to the Mean, so there is no distinctly below average, or above average results.

The values of skewness (Skew.) and kurtosses (Kurt.) distribution of the results for the entire sample of male volleyball players are generally within the normal distribution. Only the results for the motor test shooting the vertical target with fingers (SVTF), go beyond the normal distribution and show a small positive asymmetry (1.25). Certain deviations were observed in the motor test shooting the horizontal target with spike technique (SPIKE), whose value of skewness (-1.14) showed a small negative asymmetry. According to the results of the degree of curvature, or the value of kurtosis, it is estimated that homogeneity of results exists in the performance of motor tests. Given that it is about slightly longer and lower values of symmetry in the two above-mentioned motor tests, it is considered that as such they do not disturb the further processing of data, so that further statistical analysis can be safely continued, as well as the analysis of comparative statistics, and analysis of precision space of male volleyball players.

TABLE 1

Basic statistical parameters of the male volleyball players.

\begin{tabular}{lrrrccrrr}
\hline \multicolumn{1}{c}{ Variable } & \multicolumn{1}{c}{$M$} & $M I N$ & $M A X$ & Var. width & SD & SE & Skew. & Kurt. \\
\hline SHTF & 15.00 & 13.00 & 17.00 & 3.66 & 1.09 & .17 & .38 & -.45 \\
\hline SHTB & 9.35 & 4.00 & 14.00 & 5.18 & 1.93 & .30 & -.50 & 1.12 \\
\hline SVTF & 20.07 & 17.00 & 28.00 & 4.84 & 2.27 & .36 & 1.25 & 2.33 \\
\hline SVTH & 10.95 & 8.00 & 13.00 & 4.16 & 1.20 & .19 & -.28 & -.40 \\
\hline STHP2 & 9.93 & 7.00 & 14.00 & 4.57 & 1.53 & .24 & .73 & .38 \\
\hline SPIKE & 18.32 & 12.00 & 21.00 & 5.02 & 1.79 & .28 & -1.14 & 2.45 \\
\hline OHJ & 12.77 & 10.00 & 15.00 & 3.47 & 1.44 & .23 & -.02 & -1.19 \\
\hline KOONET & 5.93 & 5.13 & 7.13 & 4.44 & .45 & .07 & .74 & .06 \\
\hline KOOSP & 7.93 & 6.78 & 9.40 & 4.76 & .55 & .09 & .49 & .24 \\
\hline HEX & 22.82 & 20.93 & 25.60 & 4.86 & .96 & .15 & .64 & 1.46 \\
\hline REFL & 15.65 & 14.00 & 17.50 & 3.50 & 1.00 & .16 & -.05 & .77 \\
\hline
\end{tabular}

Legend: $M$ - Sample mena; $M I N$ - Minimum value; $M A X$ - Maximum value; Var. width

- Variational width; $S D$ - Standard deviation; $S E$ - Standard error; Skew. - Coeffcients of skewness; Kurt. - Coeffcients of kurtosis; SHTF - Shooting the horizontal target with fingers; SHTB - Shooting the horizontal target with the "bump"; SVTF - Shooting the vertical target with fingers; SVTH - Shooting the vertcal target with "bump"; STHP2 - Shooting the target in the horizontal plane from position 2; SPIKE - Shooting the horizontal target with spike technique; $\mathbf{O H J}$ - One-hand juggling a ball through a hoop; KOONET - Coordination by the volleyball net; KOOSP - Coordination in the space; HEX - Hexagon test; REFL - Falling rod.

It is noticeable that most motor tests in which the technique of passing the ball with fingers was mostly used had a better and higher value. The only exception is motor test for shooting the vertical target with fingers where the results show a variation on normal distribution, and a small negative asymmetry. Based on this value it can be said that this motor test was more demanding on some of the respondents from the sample male volleyball players and that their Mean is in area of lower values.
If we look to the tests in which a technique of adding with »bump« was used, in the realization of these tests the sample of volleyball players has achieved excellent results, and have the higher mean values. Despite this, in tests which use the forefinger manipulation with the ball, male volleyball players have better results compared to the results in tests in which they used technique of adding with "bump".

Motor tests of shooting the horizontal target with spike technique and one-hand juggling a ball through a hoop have a higher mean value, which 
indicates that the male volleyball players are generally very good in spike technique performance in which explosive power and speed of individual arm movements are dominant, as well as a skill in one-hand juggling a ball through a hoop. This is further supported by the value of skewness in the motor test of shooting the horizontal target with spike technique which shows a small positive asymmetry. We conclude that as a motor test this was relatively easy for some of the sample male volleyball players and their average values are significant.

Kalajdžić (1984) came to the similar conclusion in his research paper on the structure of the volleyball games and found that when it comes to the efficient expression technique, an explosive leg strength and speed of individual arm movements at spike have the greatest impact, as well as the whole body coordination and flexibility. Bertucci and Hippolyte (1984) based on the obtained data, have concluded that in the training process training techniques should exist as well as the necessary physical ability that should be developed (vertical jump, speed in all its manifestations). Male volleyball players have shown that they possess a high degree of coordination skills in the implementation of tests, because the results of coordination tests by the volleyball net and coordination in space are within higher test results. This coordination is manifested through a distinct coordination of arms and legs.

Current research papers of coordination clearly indicate the importance of this ability, and that it can be expressed through different forms. Horga et al. (1973) dealt with the issue of the existence of specific forms of motor coordination as well, which can certainly be associated with this research, and they established the existence of a single common factor of measurement, called hand coordination factor. Viskić Štalec et al. (1973) also found a common factor of measurement and interpreted it as the ability of coordination in performing complex motor tasks, using mainly the lower extremities.

Because of the complexity of the tasks set in this research, but also specifics of the sample (male volleyball players), without a doubt we can talk not only about the coordination of upper and lower extremities, but also the coordination of the whole body.

FIGURE 1

Graphic presentation of average values of the applied tests of the male volleyball players.

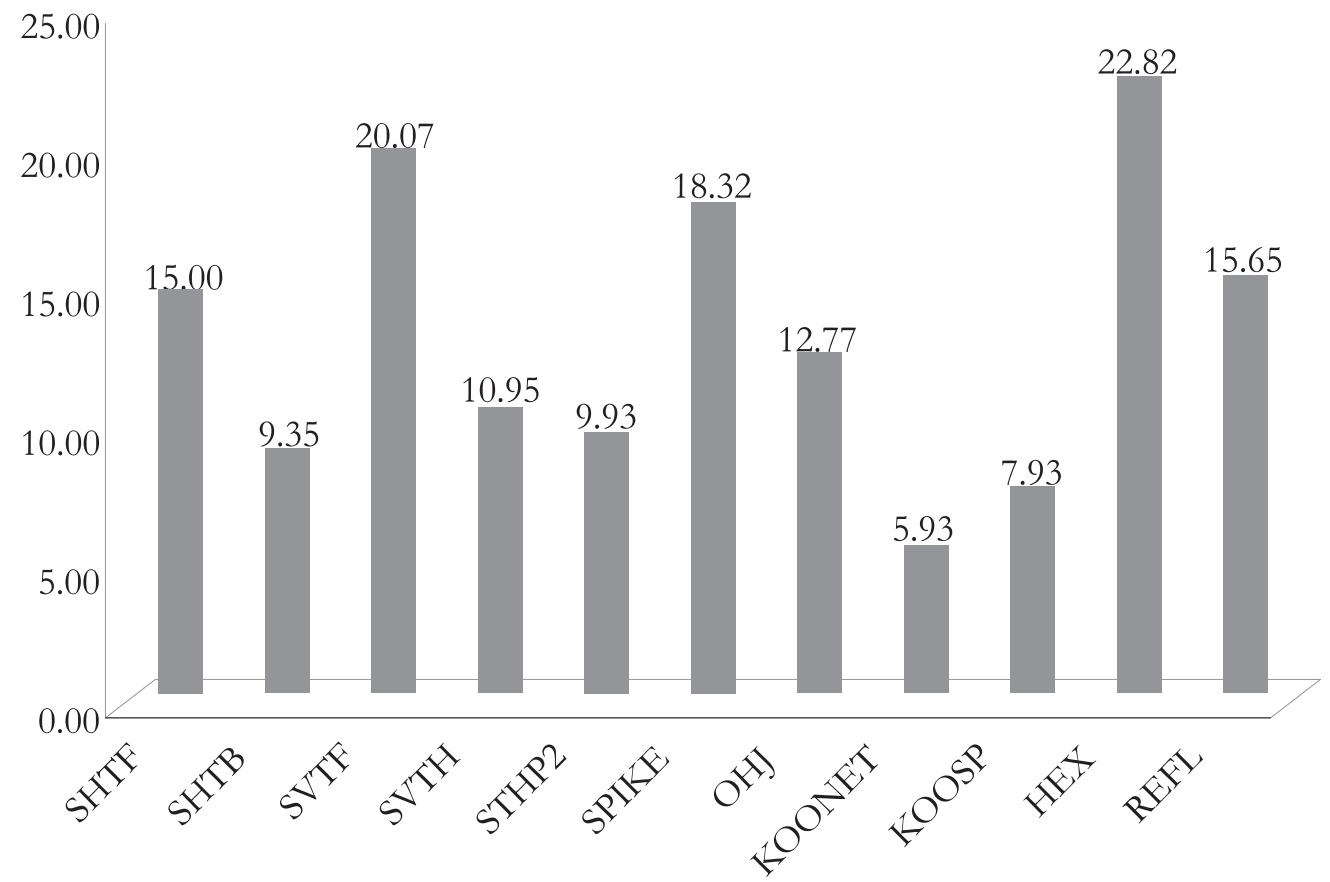

Legend: SHTF - Shooting the horizontal target with fingers; SHTB - Shooting the horizontal target with the "bump"; SVTF - Shooting the vertical target with fingers; SVTH - Shooting the vertcal target with "bump"; STHP2 - Shooting the target in the horizontal plane from position 2; SPIKE - Shooting the horizontal target with spike technique; $\mathbf{O H J}$ - One-hand juggling a ball through a hoop; KOONET - Coordination by the volleyball net; KOOSP - Coordination in the space; HEX - Hexagon test; REFL - Falling rod. 
Given that the emphasis is placed on the complexity of coordination, the relationship between cognitive ability (intelligence), and coordination is very important. This motor ability correlates highly with intelligence and it is impossible to define or analyze coordination independently of intellectual abilities. The arguments for this assertion are the results of multi- ple studies (Ismail \& Gruber, 1967; Ismail, Kane, \& Kirkendal, 1976; Mejovšek, 1977; Momirović, Dobrić, \& Karaman, 1984) which show that the relationship between intellectual and motor abilities are, in the first place the results of common factors that affect on the variability intellectual skills and coordination.

\section{TABLE 2}

Factor precision space structures of the male volleyball players.

\begin{tabular}{ccccc}
\hline Component & Eigenvalue & $\begin{array}{c}\text { \% Total } \\
\text { Variance }\end{array}$ & $\begin{array}{c}\text { Cumulative } \\
\text { Eigenvalue }\end{array}$ & $\begin{array}{c}\text { Cumulative } \\
\%\end{array}$ \\
\hline F1 & 2.16 & 19.64 & 2.16 & 19.64 \\
\hline F2 & 1.69 & 15.36 & 3.85 & 35.00 \\
\hline F3 & 1.57 & 14.30 & 5.42 & 49.30 \\
\hline F4 & 1.29 & 11.76 & 6.72 & $\mathbf{6 1 . 0 5}$ \\
\hline
\end{tabular}

Legend: F1 - Precision of shooting a target with »bump«; F2 - Body coordination in the volleyball court; F3 - Precision of shooting a target with fingers; F4 - Motor manipulation with arms and legs.

\section{TABLE 3}

Factor structure of precision of the male volleyball playrs, the main components and communality.

\begin{tabular}{lcrrrr}
\hline & F1 & F2 & \multicolumn{1}{c}{ F3 } & \multicolumn{1}{c}{ F4 } & $R^{2}$ \\
\hline SHTF & .09 & .03 & .84 & .24 & .34 \\
\hline SHTH & $\mathbf{. 8 6}$ & -.02 & .21 & -.05 & .52 \\
\hline SVTF & .29 & -.39 & -.50 & -.34 & .28 \\
\hline SVTH & $\mathbf{. 5 9}$ & .54 & .03 & -.03 & .38 \\
\hline STHP2 & $\mathbf{. 5 5}$ & .30 & .15 & -.28 & .29 \\
\hline SPIKE & -.01 & .23 & -.62 & .45 & .23 \\
\hline OHJ & .47 & -.41 & -.07 & .42 & .26 \\
\hline KOONET & -.32 & $\mathbf{- . 6 2}$ & .36 & .18 & .28 \\
\hline KOOPS & -.35 &. $\mathbf{5 3}$ & .14 & -.08 & .30 \\
\hline HEX & -.44 & .15 & .07 & $\mathbf{- . 5 6}$ & .27 \\
\hline REFL & .21 & -.49 & .05 & -.55 & .19 \\
\hline
\end{tabular}

Legend: F1 - Precision of shooting a target with »bump«; F2 - Body coordination in the volleyball court; F3 - Precision of shooting a target with fingers; F4 - Motor manipulation with arms and legs; $R^{2}$ - Multiple R-square; SHTF - Shooting the horizontal target with fingers; SHTB - Shooting the horizontal target with the "bump"; SVTF - Shooting the vertical target with fingers; SVTH - Shooting the vertcal target with "bump"; STHP2 - Shooting the target in the horizontal plane from position 2; SPIKE - Shooting the horizontal target with spike technique; $\mathbf{O H J}$ - One-hand juggling a ball through a hoop; KOONET - Coordination by the volleyball net; KOOSP - Coordination in the space; HEX - Hexagon test; REFL - Falling rod.

Relations between intellectual ability and coordination tests of movement were analyzed mainly with regression model, canonical analysis of variance (Momirović et al., 1983), or model of overlapping analysis, but the most commonly used was canonical correlation analysis (Mejovšek, 1977). The value of Mean for the motor test hexagon for a sample of male volleyball players is high, which implies poorer overall results, after the implementation of this test. 
We note that in this test the subjects were not able to attempt a trial, and reasons for the poor results can also be related to this. We can confirm that the cause of poor results was low level of concentration during the test, reduced anaerobic-aerobic endurance, and slow performance of jumps with both feet. This was further affected by fatigue during performance, and by insufficient emotional stability.

Unlike the hexagon test (HEX) results of the mean value of the motor test falling rod (REFL) is higher, and this points us to the conclusion that the male volleyball players in this test were quite successful in the realization of the task, and also they had the necessary level of concentration attention without disruptive factors, the coordination of arm movements and speed of reaction.

This is further supported by Vuković (1996), who found that in male volleyball players there are significant differences in morphological characteristics (body height, body weight, arm length, pelvic width, the width of the hand, volume shin, volume forearm) but also in latent space (longitudinal dimensions of the skeleton). In the structure of motor abilities two latent dimensions stand out, and these are explosive power and agility.

\section{Factor structure of space precision by male volleyball players}

Table 2 shows the values of the coefficient of discrimination (Eigenvalue). According to the values of the coefficient of discrimination (value $>1$ ) four main components were isolated which explain 61.05\% of common variance (Total Variance $\%$ ) of the whole system for a sample of volleyball players. The first component explains $19.64 \%$ of common variance, the second component explains $15.36 \%$ of common variance, the third component of $14.30 \%$ and fourth component only $11.76 \%$ of common variance. Communalities are presented together with significant principal components.

Table 3 shows precision space structures by male volleyball players, in fact it shows correlation of applied motor tasks with the four main components defined as factors of the researched area. Factor values higher than .304 are marked.

Respecting the hierarchy of isolated factors and the level of explanation of the total variance, the first factor (F1) in volleyball players is defined as the precision of shooting a target with »bump«. The second factor (F2) is defined as a body coordination in the volleyball court. The third factor (F3) is defined as the precision of shooting a target with fingers. And fourth, last factor (F4), which explains the smallest fraction of the total variability, is described as a motor manipulation with arms and legs.

According to these data, for the precision factor of shooting a target with »bump« statistically most contribute motor tests shooting the horizontal target with the »bump« $($ SHTB $=-.86)$, shooting the vertcal target with "bump" (SVTB = -.59) and the shooting the target in the horizontal plane from position (STHP2 $=.55)$. The minimum contribution to this factor has a one-hand juggling a ball through a hoop test $(\mathrm{OHJ}$ $=.47$ ). The highest contributing tests to the second isolated factor are: test of coordination by the volleyball net (KOONET $=-.62$ ) and the test of coordination in the space (KOOSP $=-.53$ ).

To the precision factor of shooting the target with fingers contribution comes from the tests shooting the horizontal target with fingers (SHTF $=.84$ ) and shooting the horizontal target with spike technique (SPIKE = -.62), while the smallest projection on the second factor has a test shooting the vertical target with fingers (SVTF $=-.50)$ hexagon test (HEX $=$ $-.56)$ and test evaluation of reaction time: a falling rod $($ REFL $=-.55)$ showed the biggest projection on the motor factor manipulation with arms and legs.

The first factor describes a group of motor tests which are dominated by the precision technique of passing the ball with forearms. This factor determines the tests of: shooting the horizontal target with the »bump«, shooting the vertical target with the »bump« and shooting the target in the horizontal plane from position 2 . The male volleyball players have shown best results in the test in which they had to have a very precise technique of adding with forearm to a shoot horizontal target. This confirms the mutual correlation.

Motor test of one-hand juggling a ball through a hoop is also a test that determined the precision factor of shooting a target with the »bump«. Relationship between the four motor tests can be found in concentrating on the task, good ball handling and good ball control. Coordination factor at the volleyball court was described as a second factor. This factor is determined by two tests: test coordination by the volleyball net and the test coordination in the space. Orientation in space stands out as an important feature of this test given that the task was realized in limited circumstances, namely, in the space with dimensions of a volleyball courts.

The third factor relates to the precision of shooting at a target with fingers. It is determined by these tests: shooting the horizontal target with fingers, shooting the vertical target with fingers and shooting the horizontal target with spike technique. Particular- 
FIGURE 2

Graphic presentation of the factor structure of the precision of the male volleyball players.

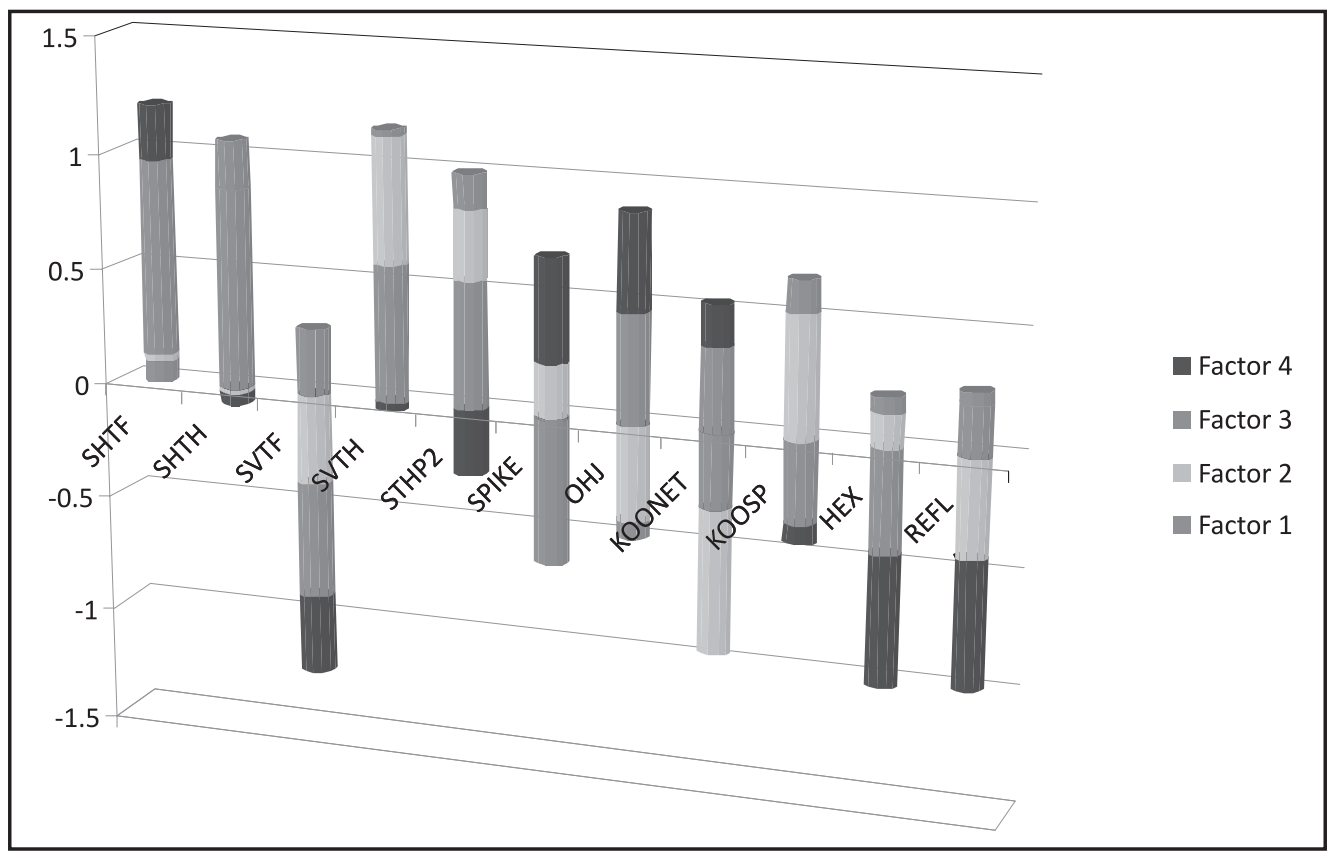

Legend: Factor 1 - Precision of shooting a target with »bump«; Factor 2 - Body coordination in the volleyball court; Factor 3 - Precision of shooting a target with fingers; Factor 4 - Motor manipulation with arms and legs; SHTF - Shooting the horizontal target with fingers; SHTB - Shooting the horizontal target with the "bump"; SVTF - Shooting the vertical target with fingers; SVTH - Shooting the vertcal target with "bump"; STHP2 - Shooting the target in the horizontal plane from position 2; SPIKE - Shooting the horizontal target with spike technique; $\mathbf{O H J}$ - One-hand juggling a ball through a hoop; KOONET - Coordination by the volleyball net; KOOSP - Coordination in the space; HEX - Hexagon test; REFL - Falling rod.

ly singled out was the first motor test which compared to other tasks within this factor seems to be the easiest to implement. This confirms the earlier conclusion that it is easier to solve problems that have assumed horizontal target shooting and one for the second sample. The connection of motor test shooting the horizontal target with spike technique with this factor can be explained by the ability to control the ball and good accuracy with one or two hands.

The fourth factor in the area of volleyball precision is defined as a factor in motor manipulation of the hands and feet. Manipulation of legs refers to the hexagon test, and manipulation of the hands to the evaluation of reaction time: test a falling rod, in which agility or the ability to quickly change direction in certain space and time dominate, but also a high degree of concentration and nerve-muscle reaction. Motor coordination of the upper and lower extremities, coordination in the rhythm and correct technique each have an important role in the realization of the set of tests.
Fleishman (1954) mostly dealt with factor analysis of the precision and is the most widely tested and has contributed to the knowledge of precision most. $\mathrm{He}$ asked for the smallest possible number of capabilities that could explain the motor behavior that requires skillful and precise movements. He found two out of ten isolated factors which could explain the precise movements. One was related to the ability to control arms in the targeting and the author called it »hands" skills. It came out from looking at variables obtained from motor tasks that required the exercise of a series of precisely focused and precise movements. The other factor is the "strength of arms and hands", which was obtained from the task in which a safe hand movement, with the minimum power and minimum speed manifest is to be obtained.

Authors (Gredeli, Metikoš, Hošek, \& Momirović, 1975; Kurelić et al., 1975) pointed to precision in an effort to define the entire space of motor skills. The common conclusion on the basis of which precision was appointed as a factor is that it can be called so but only with caution, given the insufficient number 
of measured motor manifestations that are dependent on motor skills.

\section{CONCLUSION}

Based on the results obtained the following was concluded: there are certain manifest dimensions within the research area, defined as a space precision.

Also the structure of motor skills of precision in male volleyball players, the precision factors of shooting targets with the fingers and "bump" in the horizontal and vertical planes are present. It is also confirmed that a factor of coordination in the area of volleyball court and a speed factor of nerve-muscle response are present. We can also conclude that within the structure of technical-tactical elements particular types of precision by male volleyball players operate, that can be defined as precision factors in the technique of adding with the finger, »bump « technique and spike technique. Accordingly, a motor ability of precision can be distinguished as a separate phenomenon and interpreted as a factor in the successfull set of technical - tactical structures of volleyball selected for this research.

When it comes to determining the structure of motor abilities, it is still quite unclear. Previous studies have shown that the problem of their structure only began to be dismissed. In time, with the factorial approach to the study of anthropological space, it is gathered more information to confirm that there are multiple factors and their minor or major influence which raises a new issues in the structure of motor abilities, especially the question of their mutual relations.

The results are important in the investigation area of motor skills, especially for the further study of the precision skills of male volleyball players. The volleyball coaches will be also able to effectively plan and implement the training program of technical and tactical elements. The knowledge about structure of the precision motor skills of male volleyball players, will allow teachers of physical education a better realization of volleyball program in physical education and sports and recreatives to apply volleyball for recreation and leisure time.

\section{REFERENCES}

Бернстеин, А. (1990). Физиология движений и Аеятельность [Physiology of movements and activities]. Жррнал общей биологии, 51 (2), 373-392.

Bertucci, B., \& Hippolyte, R. (1984). Championship volleyball drills. Volume 1. Champaign, IL: Leisure Press.
Bosnar, K., \& Šnajder, V. (1983). Relacije kognitivnih faktora i uspješnosti u odbojkaškoj igri [Relations between cognitive factors and performance in a volleyball game]. Kineziologija, 15(2), 123-128.

Fleishman, A. E. (1954). Dimensional analisis of psyhomotor abilities. Journal of Experimenta psychology, 48(6), 437-454.

Gajić, Z. (2005). Formiranje modela pracienja tehničkotaktickih elemenata odbojkaske igre [Establishment of model of monitoring the technical and tactical elements of a volleyball game]. (Unpublished master's thesis). University of Belgrade, Faculty of sport and physical education.

Gredelj, M., Metikoš, D., Hošek, A., \& Momirović, K. (1975). Model hijerarhijske strukture motoričkih sposobnosti [Model of the hierarchical structure of motor abilities]. Kineziologija, 5(1-2), 7-81.

Horga, S., Metikoš, D., Viskić Štalec, N., Hošek, A., Gredelj, M. ... Marčelja, D. (1973). Metrijske karakteristike mjernih instrumenata za procjenu faktora koordinacije ruku [Metric characteristics of measuring instruments for the assessment of factors hand coordinating]. Kineziologija, 3(2), 13-20.

Horga, S., Momirović, K., \& Janković, V. (1983). Utjecaj konativnih regulativnih mehanizama na uspješnost igranja odbojke [The impact of regulatory mechanisms on the performance of playing volleyball]. Kineziologija, 15(2): 129-137.

Ismail, A. H., \& Gruber, J. J. (1967). Interrelationships between motor aptitude and intellectual performance. West Lafayette, IN: Purdue University. Ismail, A. H., Kane, J. E., \& Kirkendall, D. R. (1976). Relationships among intellectual and nonintellectual variables. Res. Q, 40(1) 83-92.

Janković, V. (1988). Latentna struktura tehničkotaktičkih elemenata u odbojci [Latent structure of technical and tactical elements in volleyball]. Kineziologija, 20(1), 57-63.

Kalajdžić, D. (1984). Morfološke, motoričke, kognitivne, konativne $i$ sociološke dimenaije odbojkaša [Morphological, motor, cognitive, conative, and social dimensions of volleyball players]. (Unpublished doctoral dissertation). University of Novi Sad, Faculty of physical education.

Karalić, T. (2007). Uspješnost realizacije tehničko taktickeih elemenata na Eurposkom odbojkaskeom prvenstvu Rim - Beograd 2005 [The success of the implementation of technical - tactical elements of the European Volleyball Championships 
Rome - Belgrade 2005]. (Unpublished master's thesis). University of Banja Luka, Faculty of physical education and sport.

Kurelić, N., Momirović, K., Stojanović, M., Šturm, J., Radojević, Đ., \& Viskić Štalec, N. (1975). Struktura $i$ razvoj morfoloških $i$ motoričkih dimenzija omladine [The structure and development of morphological and motor dimensions of youth]. Belgrade, SRB: Institute for Scientific Research of the Faculty of Physical Education, University of Belgrade.

Аяхова, Т. П., \& Стрельникова, Е. Я. (2007). Оптимизация технико-тактических действий с учётом игровых амплуа волейболистов. [Optimization of the technical and tactical actions taking into account the role playing volleyball]. In C. С. Ермакова (Ed.), Физическое воспитание студентов твориеских спеииальностей (pp. 57-62). Kharkiv, Ukrainian: Kharkiv State Academy of Physical Culture.

Mejovšek, M. (1977). Relacije kognitivnih sposobnosti i nekih mera brzine jednostavnih i složenih pokreta [Relations between cognitive abilities and some measure of the speed of simple and complex movements]. Kineziologija, 7(1-2), 77-136.

Momirović, K., Dobrić, V., \& Karaman, Ž. (1983). Canonical covariance analysis. Proceedings of the 5th International Symposium »Computer at the University« (p.p. 463-473). Cavtat, CRO.

Немцев, Б. О. (2003). Место точности Авижений в структуре физического качества [Location accuracy of movements in the structure of physical qualities]. Теория и практика физическии култури, 8(4-9).

Nešić, G. (2006). Struktura takmičarske aktivnosti u ženskoj odbojci [The structure of competitive activity in women's volleyball]. (Unpublished doctoral dissertation). University of Belgrade, Faculty of sport and physical education.
Stojanović, T., \& Milenkoski, J. (2005).

Multivarijantne razlike u varijablama za procjenu situaciono-motoričkog znanja između šestorki na utakmicama plej-ofa i plej-auta Prve makedonske odbojkaške lige [Multivariate differences in variables to assess the situationalmotor skills between the six playoff games and play-out of the First Macedonian volleyball league]. Glasnik fakulteta fizičkog vaspitanja i sporta, 1, 101-111.

Stojiliković, S. (2003). Osnove opšte motorike [Fundamentals of general motor skills]. Niš, SRB: Studentski kulturni centar.

Strahonja, A. (1978). Utjecaj manifestnih i latentnih antropometrijskih varijabli na situacionu preciznost u odbojci [The impact of manifest and latent anthropometric variables on situational accuracy in volleyball]. Kineziologija, 8(1-2), 102-125.

Strahonja, A., Janković, V., \& Šnajder, V. (1982). Analiza pouzdanosti i faktorske valjanosti situaciono-motoričkih testova u odbojci [Analysis of reliability and factorial validity of the situational-motor tests in volleyball]. Kineziologija, 14(5), 161-175.

Viskić Štalec, N., Horga, S., Metikoš, D., Gredelj, M., Marčelja, \& Hošek, A. (1973). Metrijske karakteristike testova za procjenu faktora koordinacije nogu [Psychometric characteristics of tests to assess the factors coordinating the legs]. Kineziologija, 3(2), 21-27.

Vuković, M. (1996). Baterija testova za odabir mladih odbojkaša. In Zbornik radova Fakulteta fizičke kulture Novi Sad, sveska VIII sa međunarodnog simpozijuma "Tehnologija radnih procesa u fizičkoj kulturi" i "Sportske aktivnosti dece i omladine" (pp. 167-172). Aranđelovac, SRB.

Received: November 16, 2011

Revision received: April 9, 2012 Accepted: May 18, 2012

Correspodence to: Tamara Karalić, PhD Faculty of Physical Education and Sport Bulevar Vojvode Petra Bojovića 1a 78000 Banja Luka

Bosnia \& Herzegovina E-mail: tasha_k@blic.net Phone: 0038766541309 